\title{
Análise morfoanatômica comparativa da folha de Bauhinia forficata Link e B. variegata Linn. (Leguminosae, Caesalpinioideae)
}

\author{
Makeli Garibotti Lusa ${ }^{1,2}$ e Cleusa Bona ${ }^{1}$
}

Recebido em 28/11/2007. Aceito em 10/06/2008

\begin{abstract}
RESUMO - (Análise morfoanatômica comparativa da folha de Bauhinia forficata Link e B. variegata Linn. (Leguminosae, Caesalpinioideae)). Esse trabalho foi desenvolvido com o propósito de subsidiar o controle de qualidade das espécies medicinais Bauhinia forficata Link e B. variegata Linn. Essas foram coletadas em jardins e terrenos baldios de Curitiba, Paraná, Brasil. As amostras do limbo, pecíolo e pulvino foram fixadas em F.A.A. 50 e conservadas em etanol $70 \%$. O seccionamento do material foi feito em micrótomo de rotação (material incluído em historresina) ou a mão livre e as lâminas foram montadas de forma permanente ou semipermanente. Foram realizadas análises em microscopia fotônica e eletrônica de varredura. A folha de $B$. forficata é alongada, com folíolos unidos em torno da metade do limbo, ápices agudos, superfície adaxial lisa e mucro entre os folíolos. Enquanto que, $B$. variegata possui folha mais larga que longa, com folíolos unidos na porção terminal do limbo e ápices obtusos. Nos pulvinos de $B$. variegata ocorrem camadas de colênquima, ausentes em $B$. forficata. O formato e a bainha de fibras dos pecíolos, em secção transversal, são distintos entre as espécies, assim como a distribuição dos estômatos e tricomas no limbo e a forma do bordo em secção transversal. B. variegata possui maior quantidade de idioblastos com drusas e compostos fenólicos. As características morfológicas e anatômicas de B. forficata e B. variegata contribuem para a identificação e diferenciação das espécies, sendo importantes para o controle de qualidade do material destinado à pesquisa e à indústria farmacêutica.
\end{abstract}

Palavras-chave: Bauhinia, pata-de-vaca, plantas medicinais

\begin{abstract}
Comparative morphogical and anatomycal analyses of Bauhinia forficata Link and B. variegata Linn. (Leguminosae, Caesalpinioideae) leaves). This work has been developed with the purpose of helping the quality control of the medicinal species Bauhinia forficata Link and B. variegata Linn., which were collected in gardens and vacant lots in Curitiba, Paraná, Brazil. The samples of leaf blade, petiole and pulvinus were fixed in FAA 50 and preserved in alcohol 70. The sectioning of the material was made in rotational microtome (with the material included in historesine) or manually and the blades were mounted in permanent or semipermanent way. Analyses in photonic and scanning electronic microscopy were performed. The leaf of $B$. forficata is elongated, with the leaflets united around the middle of the leaf blade, acute apices, smooth adaxial surface and mucros between the leaflets. The B. variegata, on the other hand, possesses a broader than long leaf, with the leaflets united in the terminal portion of the blade and obtuse apices. In the pulvinus of $B$. variegata there are collenchyma layers, which are absent in B. forficata. The shape and the petiole fibers sheath, in cross section, are distinct in both species, as well as the distribution of the stomata and trichomes in the leaf blade and the shape of the border in transversal section. B. variegata possesses a higher quantity of idioblasts with druses and phenolic compounds. The morphologic and anatomic characteristics of $B$. forficata an B. variegata contribute to the identification and distinction of the species and they are important for the control of the material destined to research and to the pharmaceutical industry.
\end{abstract}

Key words: Bauhinia, medicinal plants, pata-de-vaca

\section{Introdução}

Algumas espécies do gênero Bauhinia são utilizadas para fins medicinais, sendo popularmente conhecidas como pata-de-vaca, unha-de-vaca, bauínia, entre outros nomes. Tais espécies podem apresentar porte arbóreo ou arbustivo e, conforme os nomes populares sugerem, apresentam uma folha fendida no meio, formando dois lobos ou folíolos, que a assemelham a uma pata de bovino. Possuem flores zigomorfas dispostas em racemos axilares que variam de cor, de acordo com a espécie e subespécie. Seus frutos são legumes - ou vagens - achatados e deiscentes (Lorenzi \& Matos 2002).

De acordo com Vaz \& Tozzi (2005), o gênero Bauhinia é bastante amplo, com cerca de 300 espécies, das quais 200 são brasileiras. Muitas delas são utilizadas como hipoglicemiantes e dentre tais espécies, B. forficata é bastante empregada com esse fim (Lorenzi \& Matos 2002). B. forficata é uma espécie nativa da América do Sul, a qual possui distribuição na Argentina,

\footnotetext{
1 Universidade Federal do Paraná, Departamento de Botânica, Centro Politécnico, Rua Francisco H. de Souza, C. Postal 19031, 81531-990 Curitiba, PR, Brasil

2 Autor para correspondência: makelilus@yahoo.com.br
} 
Paraguai, Uruguai, Bolívia e Brasil, sendo que no Brasil, se distribui nos Estados de Alagoas, Bahia, Espírito Santo, Minas Gerais, Paraná, Pernambuco, Piauí, Rio de Janeiro, Santa Catarina e São Paulo (Vaz \& Tozzi 2005). Espécies exóticas como B. variegata, Bauhinia blakeana Dunn. e Bauhinia monandra Kurz. são utilizadas como ornamentais em jardins e praças, sendo amplamente distribuídas. Apesar de existirem poucos estudos a cerca de tais espécies exóticas, ainda assim, a população as utiliza para os mesmos fins terapêuticos das espécies nativas (Lorenzi \& Matos 2002).

Estudos de natureza fitoquímica indicam a presença de glicosídios, ácidos orgânicos, sais minerais, taninos, pigmentos e mucilagens nas espécies de Bauhinia (Lorenzi \& Matos 2002). Souza et al. (2004) demonstram o efeito hipoglicêmico e potencial antioxidante do flavonóide Kaempferitrina em $B$. forficata, sendo confirmado o potencial contra diabetes por Pepato et al. (2004) e por Menezes et al. (2007), através de estudos com o decocto aquoso e com extrato aquoso, respectivamente. As folhas dessa espécie são consideradas, além de antidiabéticas, diuréticas (Silva \& Cechinel Filho 2002) e hipocolesterolemiantes (Lorenzi \& Matos 2002). Além disso, estudos recentes com B. forficata (Oliveira et al. 2005) atribuem propriedades anticoagulantes e antifibrinogenolíticas à mesma, enquanto que extratos de caules e cascas mostraram efetiva ação antimicrobiana, contra dermatófitos fúngicos (Silva \& Cechinel Filho 2002).

Estudos realizados com extratos etanólicos de $B$. variegata revelam atividade quimiopreventiva e efeitos citotóxicos sobre tumores de fígado de rato e linhagens celulares cancerígenas humanas (Rajkapoor et al. 2006). Contudo, é importante salientar que tal estudo foi realizado sobre amostras de B. variegata coletadas em Salem, Índia, onde a espécie é nativa e, portanto, está sob condições diferentes das brasileiras, podendo variar sua composição fitoquímica. Além disso, os efeitos terapêuticos de B. variegata sequer assemelham-se àqueles atribuídos à espécie nativa $B$. forficata - com exceção do efeito hipoglicemiante em ratos, obtido através das sementes de B. variegata (Silva \& Cechinel Filho 2002). Desse modo, qualquer troca, intencional ou não, que se faça entre as partes comercializadas de tais espécies, pode resultar em efeitos indesejados.

Existe um grande número de trabalhos publicados a cerca de $B$. forficata, no entanto, nada consta sobre diferenças e/ou semelhanças entre $B$. forficata e B. variegata no âmbito morfoanatômico. Portanto, no presente trabalho são caracterizadas as estruturas morfológicas e anatômicas de ambas as espécies visando subsidiar o controle de qualidade no comércio e na industrialização das mesmas. Além disso, a descrição de plantas nativas vem a somar no reconhecimento da biodiversidade brasileira.

\section{Material e métodos}

O material botânico das espécies de Bauhinia forficata Link e Bauhinia variegata Linn. foi coletado durante os meses de agosto/2006 a abril/2007. $B$. forficata foi coletada em terreno baldio, situado na Rua Augusto dos Anjos s.n., Bairro Barreirinha, Curitiba, PR (coordenadas $25^{\circ} 22^{\prime} 03^{\prime \prime} \mathrm{S}$ e $49^{\circ} 16^{\prime} 11^{\prime \prime} \mathrm{W}$ ). B. variegata foi coletada no Campus Centro Politécnico da Universidade Federal do Paraná (UFPR), (coordenadas $25^{\circ} 27^{\prime} 02^{\prime \prime}$ S e $49^{\circ} 13^{\prime} 47^{\prime \prime} \mathrm{W}$ ), e num terreno próximo (coordenadas $25^{\circ} 27^{\prime} 23^{\prime \prime} \mathrm{S}$ e $49^{\circ} 14^{\prime} 04^{\prime \prime} \mathrm{W}$ ). As exsicatas foram depositadas no herbário UDESC de Lages e MBM de Curitiba, onde se encontram tombadas sob os registros: MBM330658 (B. forficata), MBM330659 (B. variegata) e MBM330660 (B. variegata).

Para a análise morfoanatômica foram coletadas amostras de folhas do segundo ao oitavo nós. As amostras foram fixadas em F.A.A. 50 (Johansen 1940) e conservadas em etanol 70\%. Foram montadas lâminas semipermanentes e permanentes. Para a confecção das lâminas semipermanentes foram efetuadas secções transversais, longitudinais e paradérmicas nos pulvinos, peciolos e lâminas foliares. As amostras foram seccionadas a mão livre, clarificadas ou não com água sanitária comercial (sendo que aquelas clarificadas foram lavadas várias vezes em água destilada) e coradas com Azul de Toluidina (O’Brien et al. 1965); Azul de Astra ( $1 \%$ em água destilada) e Fucsina Básica $(0,02 \%$ em água destilada). As amostras foram ainda dissociadas com solução de peróxido de hidrogênio e ácido acético (Kraus \& Arduin 1997), lavadas várias vezes em água destilada e coradas com Azul de Astra e Safranina; ou em Safranina ( $0,5 \%$ em água destilada) (Kraus \& Arduin 1997). As lâminas semipermanentes foram montadas em gelatina glicerinada (Kaiser apud Kraus \& Arduin 1997) e vedadas com esmalte de unha incolor.

Para a confecção de lâminas permanentes foram incluídas em historresina, amostras dos pecíolos, pulvinos e lâminas foliares na região do bordo, nervura central e regiões internervurais do terço médio. As secções transversais foram efetuadas em micrótomo de rotação e os cortes, com $6 \mu \mathrm{m}$ de espessura, foram corados com Azul de Toluidina (O'Brien et al. 1965), sendo as lâminas montadas em resina sintética (Permount ${ }^{\circledR}$ ).

Foram realizados testes histoquímicos para identificação de amido, compostos fenólicos e lignina. Para os testes para verificação de amido foi utilizado lugol (Berlyn \& Miksche 1976) sobre material fixado 
198 Lusa \& Bona: Análise morfoanatômica comparativa da folha de Bauhinia forficata Link e B. variegata Linn. ...

em F.A.A. 50, seccionado a mão livre, ou incluído em historresina e seccionado em micrótomo de rotação. Para a visualização de compostos fenólicos, o material foi fixado em formalina e sulfato ferroso (Schneider 1977), incluído em historresina, seccionado em micrótomo de rotação e as lâminas montadas com resina sintética (Permoult ${ }^{\circledR}$ ). Para identificação de lignina, foram realizados cortes a mão livre, que foram testados com floroglucinol acidificado (Johansen 1940).

As análises microscópicas e registros fotomicrográficos foram realizados em microscópio fotônico ou esteroscópico da marca ZEISS Axiolab, com câmara digital fotográfica Sony Ciber-shot P200® acoplada. A impressão das folhas inteiras (secas e prensadas), para visualização do padrão de nervuras, foi realizada com papel sulfite e grafite. Os desenhos anatômicos foram efetuados através de microscópio fotônico Olympus CBA, com câmara clara acoplada e passados a nanquim em papel vegetal. As escalas foram projetadas nas mesmas condições ópticas. O padrão de nervação foi denominado de acordo com Hickey (1974).

Para a análise da superfície foliar foram realizadas observações em microscopio eletrônico de varredura (MEV). O material foi fixado em FAA 50 (Johansen 1940), desidratado em série etílica crescente até etanol absoluto e seco via ponto crítico com $\mathrm{CO}_{2}$, em equipamento BAL-TEC CPD-030. As amostras foram fixadas em suporte metálico, com uma mistura de esmalte incolor e grafite e metalizadas com ouro em equipamento SCD 030 Balzers Union FL 9496. As observações e eletromicrografias foram realizadas em Microscópio Eletrônico de Varredura JEOL JSM 6360LV Scanning Electron Microscope.

\section{Resultados}

\section{Bauhinia forficata Link}

Bauhinia forficata apresenta acúleos nos ramos e flores brancas. As folhas são compostas, com dois folíolos fundidos, pecioladas, com dois pulvinos nas extremidades do pecíolo, sendo um proximal, inserido no caule e outro distal, inserido na base do limbo (Fig. 1). A lâmina foliar é bifoliolada, simétrica e de consistência herbácea, com superfícies adaxial glabra e abaxial pilosa. Os folíolos apresentam-se unidos até a metade do limbo. Nesse ponto de união observa-se a presença de um mucro (apêndice) (Fig. 1). O ápice dos folíolos é agudo, a base do limbo é levemente cordada e a margem é inteira. O padrão de nervação é do tipo actinódromo. Cada folíolo possui cerca de cinco nervuras primárias, que saem radialmente do mesmo ponto e convergem nos bordos para formar a nervura marginal. A nervura da região de fusão dos folíolos foi considerada como nervura central da folha e apresenta menor calibre em relação às nervuras primárias do folíolo. As nervuras secundárias são curvadas e conectam-se às primárias (Fig. 1). As nervuras terciárias são percurrentes, ou seja, opostas às secundárias, fusionando-se a estas, sendo simples ou ramificadas. As nervuras quaternárias são, em geral, ortogonais, isto é, originam-se em ângulo reto. Finalmente, as nervuras quinquenárias são dispostas ao acaso, na sua maior parte.

O pecíolo, em secção transversal, possui forma elíptica, com duas projeções laterais, na superfície adaxial (Fig. 2). O pulvino proximal, em secção transversal, possui formato arredondado (Fig. 3), enquanto que o pulvino distal possui formato elíptico (Fig. 4).

A epiderme do pecíolo é unisseriada e apresenta células arredondadas, recobertas por cutícula delgada (Fig. 5). Na superfície adaxial, tais células apresentam compostos fenólicos. Internamente à epiderme, ocorre uma faixa descontínua de colênquima, seguida de parênquima cortical e uma extensa bainha de fibras, que envolve o cilindro vascular (Fig. 5). O feixe vascular é colateral, e na porção mediana do pecíolo, divide-se em dois. Dessa forma é possível observar um feixe maior voltado para a face abaxial e um menor, em início de divisão, voltado para a face adaxial (Fig. 2). No centro do pecíolo ocorre medula parenquimática com grãos de amido e idioblastos contendo drusas. O tecido floemático possui numerosos idioblastos com compostos fenólicos, drusas e monocristais (Fig. 6). Já o xilema apresenta poucos idioblastos fenólicos, localizados nas células do parênquima axial. A medida em que se aproximam do pulvino distal, os dois feixes vasculares se dividem em quatro.

A epiderme do pulvino é unisseriada com cutícula espessa, cujas células são geralmente, quadrangulares. Internamente a epiderme, observa-se um extenso córtex, constituído de células parenquimáticas de grande tamanho e de idioblastos drusíferos e, menos freqüentemente, de idioblastos com compostos fenólicos (Fig. 7). Nessa região os espaços intercelulares e os núcleos das células são evidentes. Na porção mais interna do parênquima cortical, algumas camadas celulares apresentam grãos de amido, constituindo uma bainha amilífera. Várias camadas de tecido colenquimatoso (Fig. 8), com células curtas ou pouco alongadas, de parede espessada e não lignificada, ocorrem internamente ao parênquima cortical, delimitando o cilindro vascular (Fig. 8). No pulvino proximal o cilindro vascular é constituído, na porção inicial, de um feixe vascular praticamente concêntrico, delimitando uma medula parenquimática (Fig. 3). Esse feixe, à medida que se aproxima do pecíolo, subdivide-se em cerca de quatro 

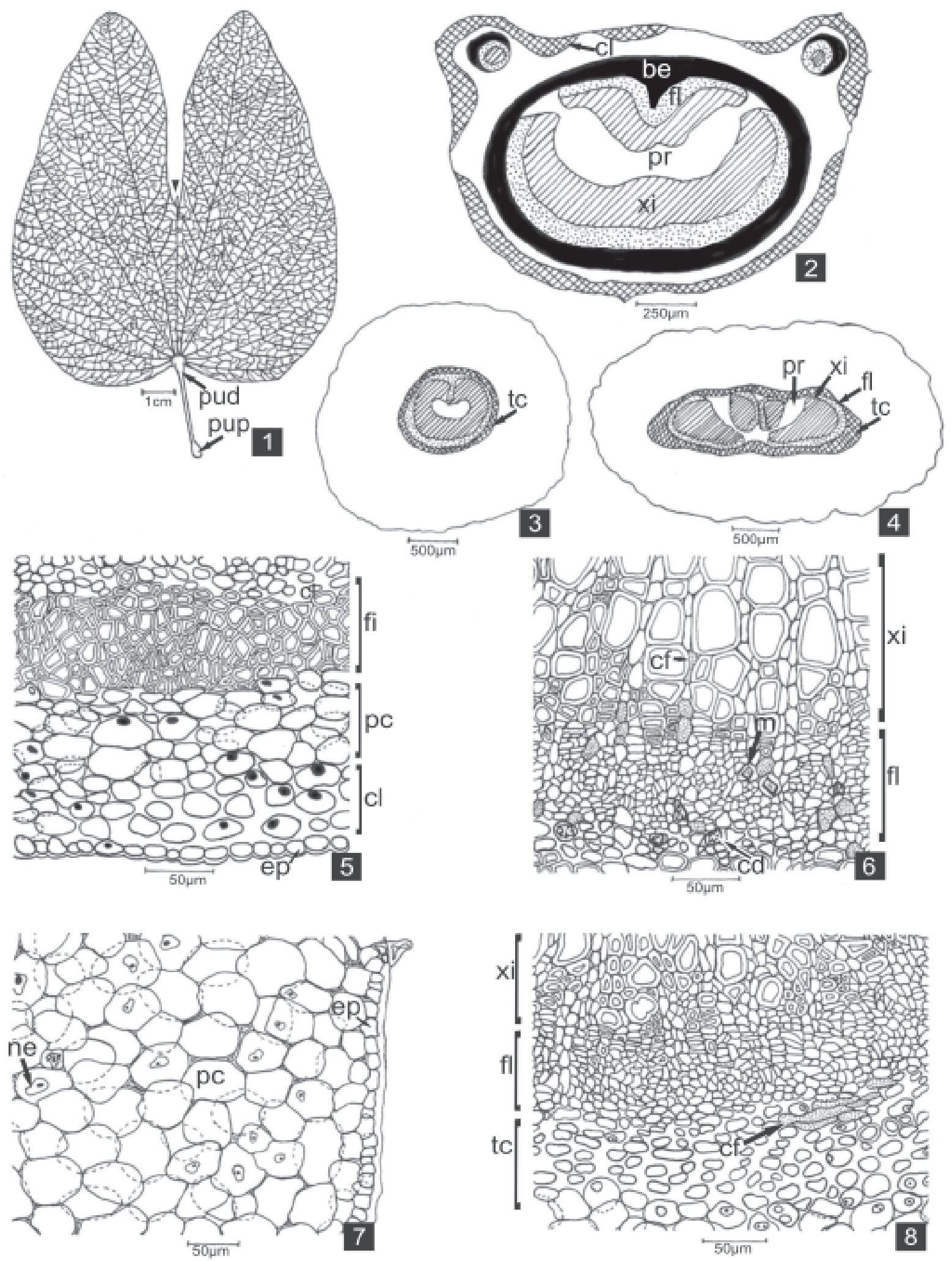

Figuras 1-8. Bauhinia forficata Link. 1. Diagrama da folha com venação em destaque. Cabeça de seta indica o mucro. 2-8. Secções transversais. 2. Diagrama do pecíolo. 3. Diagrama do pulvino proximal. 4. Diagrama do pulvino distal. 5. Detalhe dos tecidos da porção externa do pecíolo. Notar bainha de fibras (fi). 6. Detalhe dos tecidos da porção interna do pecíolo. 7. Detalhe dos tecidos da porção externa do pulvino proximal. 8. Detalhe dos tecidos da porção interna do pulvino proximal. (be - bainha esclerenquimática, cd - cristais drusíferos, cf - compostos fenólicos, cl - colênquima, ep - epiderme, fi - fibras, fl - floema, m - monocristais, ne - núcleos evidentes, pc - parênquima cortical, pr - parênquima, pud - pulvino distal, pup - pulvino proximal, tc - tecido colenquimatoso, xi - xilema). 
feixes menores. O floema possui poucas fibras e idioblastos fenólicos, além dos elementos de tubo crivado e células companheiras, enquanto que o xilema apresenta muitas fibras com paredes espessadas e parênquima, associados aos elementos de vaso (Fig. 8). O pulvino distal possui estrutura anatômica semelhante àquela descrita para o pulvino proximal, com exceção da maior extensão da bainha colenquimatosa e da conformação do cilindro vascular. Este é composto de quatro feixes colaterais - dois laterais maiores e dois centrais menores (Fig. 4) - os quais são delimitados por camadas de células parenquimáticas (no centro do cilindro vascular) e colenquimatosas (na periferia).

O pecíolo, em vista frontal, apresenta em geral, células epidérmicas quadrangulares alongadas e tricomas tectores e glandulares (naviculares) (Fig. 9). Os tectores são alongados, de tamanho variado, enquanto os glandulares possuem formato navicular, são curvilíneos e alongados horizontalmente, em relação à superfície. Os pulvinos, proximal e distal, observados em vista frontal, apresentam superfície ondulada, devido à movimentação foliar nictinástica e/ou heliotrópica. As células da epiderme, vistas frontalmente, apresentam forma arredondada ou elíptica. Tricomas tectores e glandulares naviculares são visualizados sobre toda a superfície dos pulvinos e ocorrem de forma mais abundante em relação aqueles observados no pecíolo (Fig. 10).

Ambas as faces da folha são recobertas por cera epicuticular em forma de placas que se agrupam formando estruturas estreladas (Fig. 11-12). A cera é mais conspícua na face abaxial. A face adaxial da epiderme é totalmente desprovida de tricomas, enquanto que na abaxial ocorrem tricomas tectores alongados de diversos tamanhos (Fig. 13), distribuídos sobre todo o limbo e com maior freqüência sobre as nervuras. Nessas, também são comuns tricomas glandulares do tipo navicular (Fig. 14). Os tricomas tectores são unisseriados, com número de células variando de uma a seis (Fig. 17). Os tricomas glandulares são multisseriados, com formato curvilíneo (Fig. 18).

A face adaxial da epiderme do limbo, em vista frontal, apresenta células poliédricas com paredes ligeiramente curvas. A presença de estômatos, nesta face, é esporádica, ocorrendo próximo às nervuras. Os estômatos são do tipo anomocítico, com número de células circundantes variável (de duas a sete) (Fig. 15). A face abaxial da epiderme, em vista frontal, também possui células poliédricas, porém, com paredes anticlinais mais retas e células menores que as da face adaxial. Os estômatos são freqüentes por toda a epiderme, sendo, como na face adaxial, do tipo anomocíticos (Fig. 16).
O limbo em secção transversal (Fig. 19-24) apresenta epiderme uniestratificada em ambas as faces. A cutícula é mais espessa na face adaxial, com células quadrangulares ou arredondadas, a maioria com compostos fenólicos. Na face abaxial, as células possuem diversas formas e tamanho reduzido, com parede periclinal externa papilosa (Fig. 22). O mesofilo é composto de três a cinco camadas de parênquima clorofiliano, predominantemente paliçádico, com células mais alongadas na face adaxial e quase isodiamétricas na face abaxial (Fig. 22, 24). Idioblastos com drusas ocorrem de forma esparsa ao longo do mesofilo. A região do limbo entre as nervuras primárias apresenta muitos feixes vasculares colaterais de pequeno porte. Esses possuem calota de fibras em ambas as faces (Fig. 19-22).

Na região da nervura central, a secção transversal da folha mostra células epidérmicas arredondadas com tamanho reduzido, em relação ao restante do limbo (Fig. 23), muitas dessas, contendo compostos fenólicos. Camadas de colênquima estão presentes nos ângulos, entre o mesofilo e a nervura, internamente à epiderme da face adaxial e em faixa descontínua na face abaxial (Fig. 21). A maior parte da região cortical da nervura central é parenquimática, composta de células arredondadas com alguns idioblastos fenólicos (Fig. 23). Uma bainha bastante extensa de fibras envolve completamente o feixe vascular (Fig. 21, 23), sendo seguida internamente, por parênquima. $\mathrm{O}$ xilema e floema estão dispostos em arco com o xilema voltado para a face adaxial e o floema para a abaxial (Fig. 21). O parênquima vascular também possui idioblastos fenólicos (Fig. 23).

O bordo foliar apresenta, transversalmente, forma terminal arredondada e dilatada, devido à presença de um grande feixe vascular (Fig. 20, 24). As células epidérmicas são quadrangulares a arredondadas, de tamanho reduzido na porção terminal do bordo e ligeiramente papilosas, de tamanho irregular na face abaxial (Fig. 24). Internamente à epiderme ocorre, na extremidade do bordo, uma faixa de colênquima, seguida por células parenquimáticas. O parênquima clorofiliano envolve parcialmente o feixe vascular. Uma bainha de fibras descontínua circunda tal feixe (Fig. 20, 24). O parênquima no bordo, inclusive do floema e xilema, possui idioblastos cristalíferos.

\section{Bauhinia variegata Linn.}

Bauhinia variegata não apresenta acúleos nos ramos e suas flores são cor-de-rosa, na maioria das subespécies, podendo também apresentar flores brancas. Possui, igualmente a B. forficata, folhas compostas, com dois folíolos fundidos, pecioladas e com dois pulvinos, 

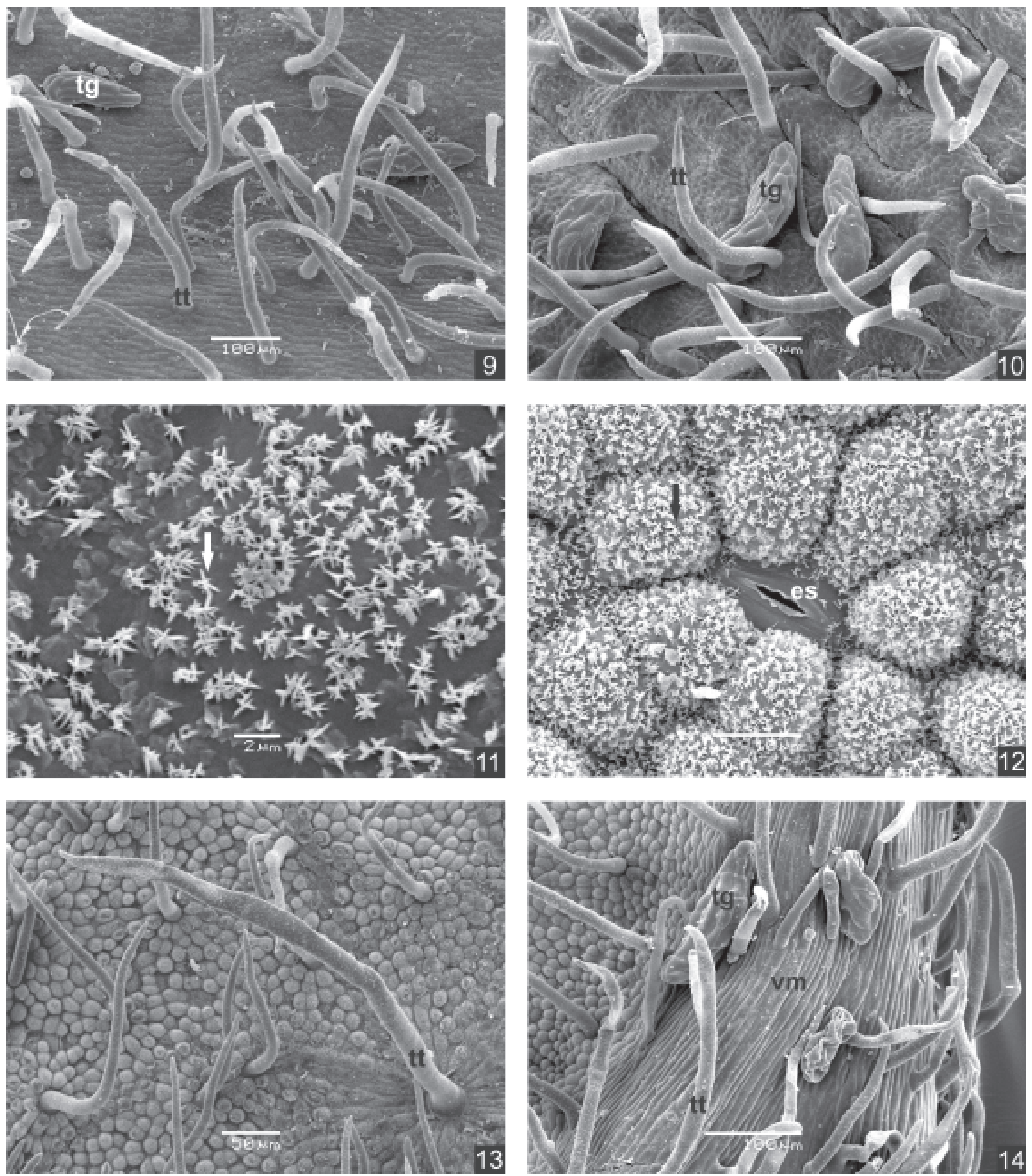

Figuras 9-14. Bauhinia forficata Link. Eletromicrografias em MEV. 9. Superfície abaxial do pecíolo. 10. Superfície do pulvino proximal. Notar ondulações. 11. Superfície adaxial do limbo recoberta por cera (seta). 12 e 13. Superfície abaxial do limbo recoberta por cera (seta); observar estômatos (12) e tricomas tectores (13). 14. Superfície do bordo foliar. (es - estômato, tg - tricoma glandular, tt - tricoma tector, vm - nervura marginal) 

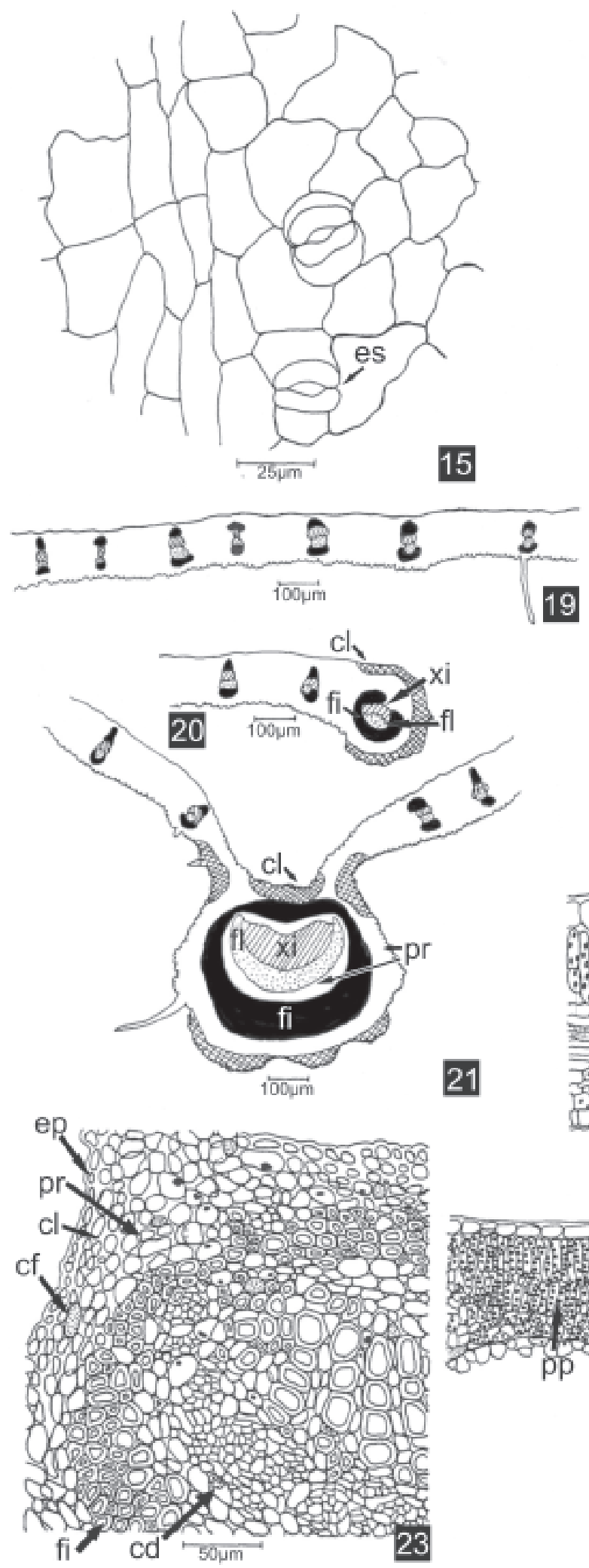
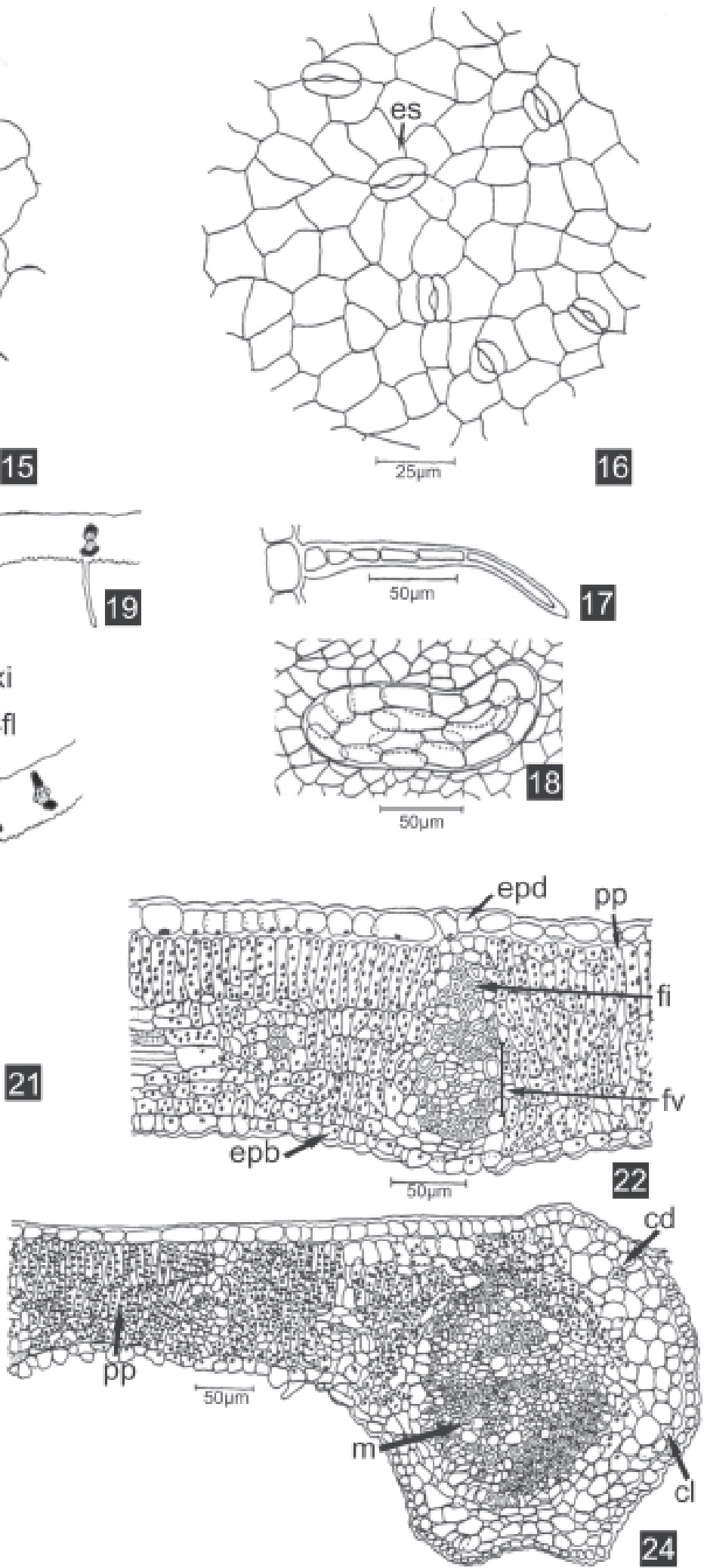

Figuras 15-24. Bauhinia forficata Link. 15, 16, 17 e 18. Secções paradérmicas. Demais figuras, secções transversais.15. Epiderme da face adaxial. 16. Epiderme da face abaxial. 17. Tricoma tector. 18. Tricoma glandular navicular em vista frontal. 19. Diagrama do limbo, região mediana. 20. Diagrama do bordo. 21. Diagrama da nervura central. 22. Detalhe dos tecidos do limbo. 23. Detalhe dos tecidos da nervura central. 24. Detalhe dos tecidos do bordo (cd - cristais drusíferos, cf - compostos fenólicos, cl - colênquima, epb - epiderme da face abaxial, epd - epiderme da face adaxial, es - estômato, fi - fibras, fl - floema, m - monocristais, pp - parênquima paliçádico, xi - xilema). 
proximal e distal (Fig. 25). O limbo é bifoliolado e simétrico, com consistência cartácea e ambas as superfícies pilosas. Os folíolos possuem ápices obtusos e se unem na porção terminal da folha, com o ponto de união a cerca de um quarto do comprimento foliar. Não foi constatada a presença de mucro na união dos folíolos. A base da lâmina é cordada e sua margem inteira. O padrão de venação é do tipo actinódromo. Cada lobo apresenta, em geral, seis nervuras primárias, saindo radialmente do mesmo ponto, e convergindo nos bordos para formar a nervura marginal (Fig. 25). A nervura central da folha possui menor calibre em relação às nervuras primárias dos folíolos. Assim como em $B$. forficata, as nervuras secundárias são curvadas e conectam-se às primárias, contudo, fazendo-se presentes, principalmente, próximo às margens, no ápice e na base da folha. As nervuras terciárias são percurrentes, sendo geralmente simples. As nervuras quaternárias são em geral, ortogonais, assim como as nervuras quinquenárias.

O pecíolo, em secção transversal, possui formato aproximadamente arredondado, ocorrendo projeções laterais junto à superfície adaxial (Fig. 26). O pulvino proximal apresenta formato arredondado enquanto que o distal é elíptico (Fig. 27, 28).

De forma geral, tanto o pecíolo, quanto os pulvinos e a lâmina foliar apresentam tricomas tectores e glandulares. Os tricomas tectores são unisseriados, com número de células variável, geralmente de uma a quatro (Fig. 29). Os tricomas glandulares naviculares são multisseriados com até três camadas de células (Fig. 30).

A epiderme do pecíolo é recoberta por cutícula delgada e possui células de formato arredondado a elíptico. Internamente à epiderme, o córtex é composto de algumas camadas de colênquima, seguido por diversas camadas de parênquima (Fig. 31). Esse possui espaços intercelulares conspícuos, especialmente próximo às projeções laterais, além de idioblastos contendo compostos fenólicos, drusas e monocristais. Uma bainha de esclerênquima circunda o cilindro central e os feixes vasculares nas projeções (Fig. 26). As fibras do esclerênquima são de natureza gelatinosa, na sua maioria (Fig. 31). O tecido vascular é composto de um grande feixe concêntrico, que envolve um feixe colateral menor, no centro da medula parenquimática e dois feixes colaterais próximos às projeções (Fig. 26). O floema contém inúmeros idioblastos fenólicos e alguns drusíferos e o xilema é composto de grandes elementos de vasos, fibras e parênquima (Fig. 32). A medula parenquimática possui algumas células com grãos de amido.

O pulvino, em secção transversal, apresenta epiderme unisseriada formada por células poliédricas com cutícula espessa e algumas contendo compostos fenólicos (Fig. 33). Internamente à epiderme, o córtex é constituído de camadas de colênquima, seguidas de parênquima com grande quantidade de idioblastos com drusas e compostos fenólicos (Fig. 33). As camadas mais internas do parênquima cortical possuem células com grãos de amido. Circundando o cilindro central, ocorre uma faixa de tecido colenquimatoso composto por células curtas ou pouco alongadas com paredes espessadas não lignificadas (Fig. 27) com fibras intercaladas, que ocorrem normalmente isoladas. $\mathrm{O}$ cilindro central do pulvino proximal é composto de um feixe concêntrico (Fig. 27) que, conforme se aproxima do pecíolo, subdivide-se em cerca de cinco feixes vasculares colaterais. No floema podem ser visualizadas, além dos elementos crivados e células companheiras, fibras, cristais drusíferos e muitos idioblastos fenólicos (Fig. 34). As calotas e os arcos xilemáticos apresentam elementos de vasos e fibras em grande quantidade (ambos com paredes bastante espessadas), intercalados por faixas de parênquima (Fig. 34). O pulvino distal, em secção transversal, apresenta a estrutura anatômica semelhante àquela do pulvino proximal, com exceção, do sistema vascular, que se organiza em cerca de quatro feixes vasculares colaterais, sendo dois externos e maiores e dois centrais menores (Fig. 28). Além desses, um grupo de cinco pequenos feixes ocorre na porção central inferior do cilindro vascular.

O pecíolo, em vista frontal, possui células epidérmicas retangulares alongadas com cutícula lisa e tricomas tectores (Fig. 35) e glandulares com formato navicular. Tais tricomas são semelhantes àqueles observados nos pulvinos, porém, sua presença é menos conspícua. Os pulvinos proximal e distal, em vista frontal, apresentam superfície com ondulações, devido à movimentação nictinástica e/ou heliotrópica. A epiderme é recoberta por tricomas tectores e tricomas glandulares naviculares (Fig. 36).

A superfície da lâmina foliar é recoberta por cera epicuticular em forma de placas, em ambas as superfícies da folha, estando mais densa na superfície abaxial (Fig. 37-39). Os tricomas que ocorrem na lâmina foliar são semelhantes àqueles descritos nos pulvinos e pecíolos, no entanto, se encontram em posição paralela à superfície e não, em posição perpendicular (Fig. 37, 40). Os tricomas tectores são visualmente menores que os do pecíolo e pulvinos e com tamanho mais uniforme em relação aos mesmos. Esses são visualizados em ambas as superfícies, sendo mais freqüentes na face abaxial e sobre as nervuras. Os tricomas glandulares naviculares ocorrem em todo o limbo, mas principalmente sobre as nervuras e bordo (Fig. 37, 40). A face adaxial da epiderme apresenta células poliédricas de 

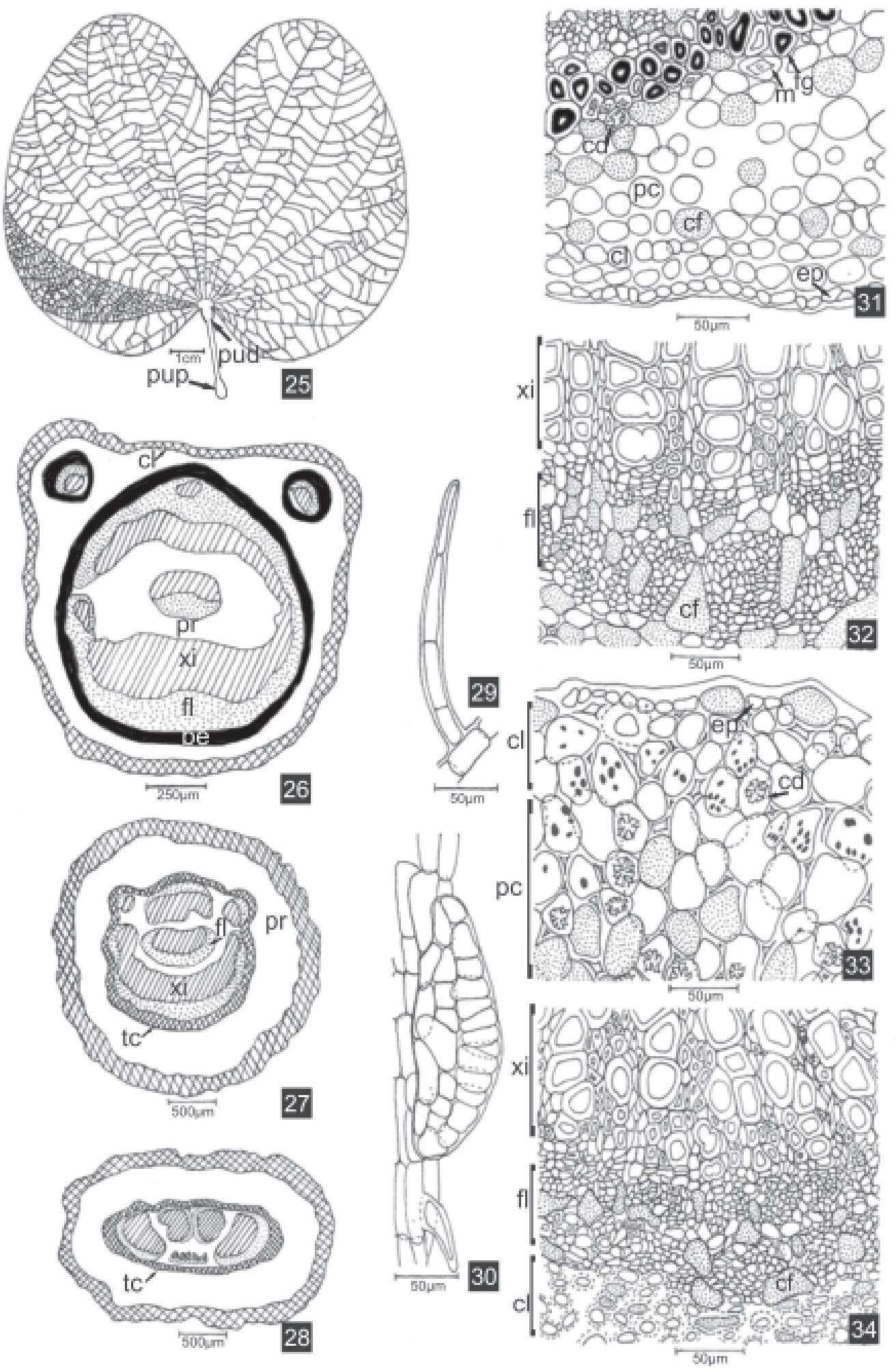

Figuras 25-34. Bauhinia variegata Linn. 25. Diagrama da folha com venação em destaque. 29 e 30. Secções paradérmicas. Demais figuras, secções transversais. 26. Diagrama do pecíolo. 27. Diagrama do pulvino proximal. 28. Diagrama do pulvino distal. 29. Tricoma tector. 30. Tricoma glandular navicular; vista lateral. 31. Detalhe dos tecidos da porção externa do pecíolo. 32. Detalhe dos tecidos da porção interna do pecíolo. 33. Detalhe dos tecidos da porção externa do pulvino proximal. 34. Detalhe dos tecidos da porção interna do pulvino proximal. (be- bainha esclerenquimática, cd - cristais drusíferos, cf - composto fenólicos, cl - colênquima, ep - epiderme, fg - fibras gelatinosas, fl - floema, m - monocristais, pc - parênquima cortical, pr - parênquima, pud - pulvino distal, pup - pulvino proximal, tc - tecido colenquimatoso, xi - xilema). 

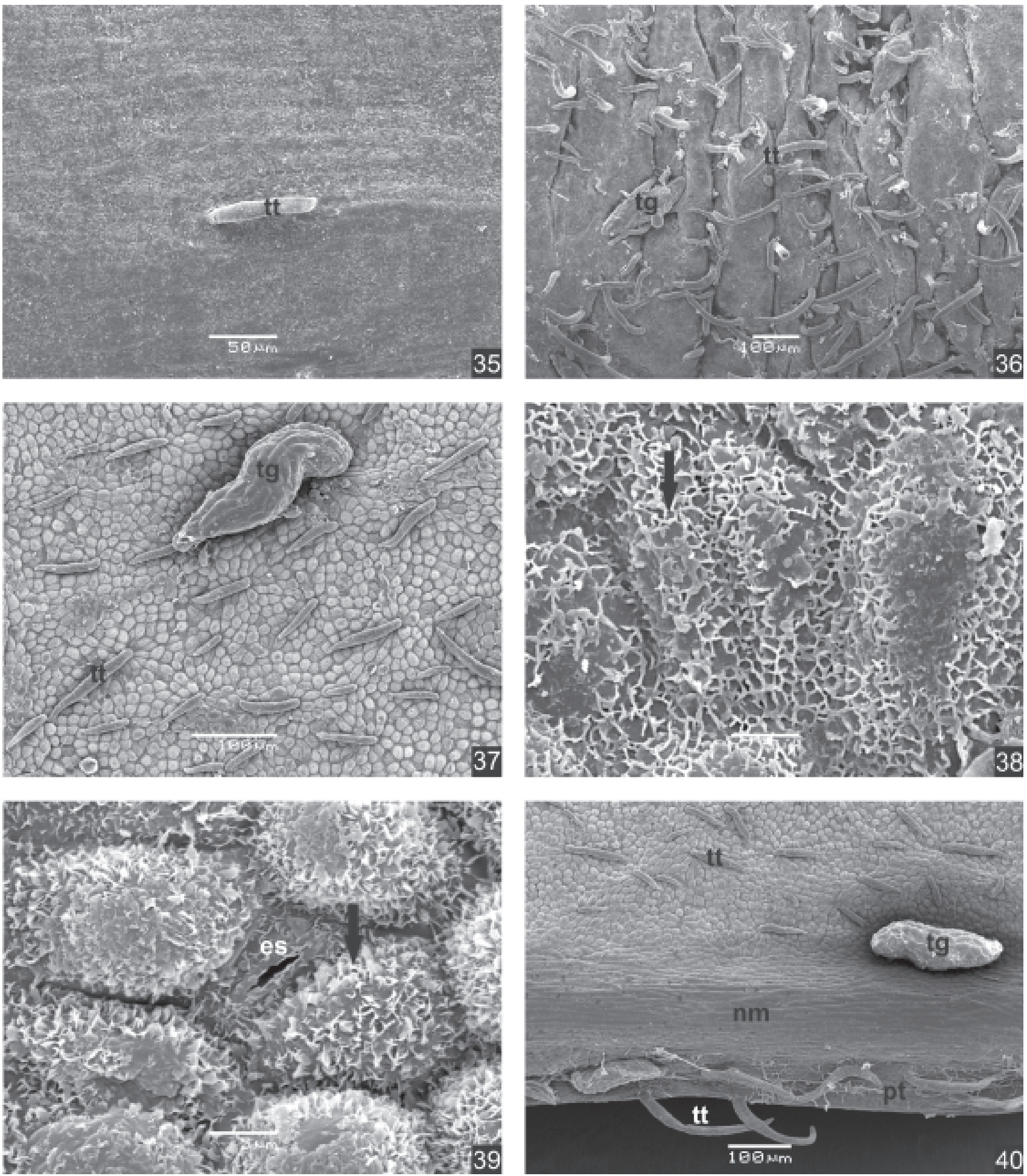

Figuras 35-40. Bauhinia variegata Linn. Eletromicrografias em MEV. 35. Superfície adaxial do pecíolo. 36. Superfície abaxial do pulvino proximal com ondulações. 37 e 39. Superfície abaxial do limbo recoberta por cera (seta). 38. Superfície adaxial do limbo recoberta por cera (seta). 40. Superfície abaxial do limbo com detalhe do bordo. (es - estômato, pt - projeção terminal, tg - tricoma glandular, tt - tricoma tector, $\mathrm{nm}$ - nervura marginal). 
206 Lusa \& Bona: Análise morfoanatômica comparativa da folha de Bauhinia forficata Link e B. variegata Linn. ...

tamanhos variáveis, com paredes anticlinais levemente curvas e estômatos anomocíticos, com número variável de células circundantes (de duas a seis) (Fig 41). A superfície abaxial, igualmente, apresenta células poliédricas, de tamanho reduzido, com paredes anticlinais mais retas (Fig. 42). Os estômatos ocorrem em maior quantidade nesta face possuindo os mesmos padrões observados na epiderme da face adaxial.

O limbo, em secção transversal (Fig. 43-48), apresenta epiderme com cutícula mais espessa na face adaxial. As células epidérmicas são arredondadas a elípticas, de grande porte nas regiões internervurais e papiliformes de pequeno porte sobre as nervuras. Algumas células epidérmicas, da face adaxial, são mucilaginosas (Fig. 47). As células epidérmicas da face abaxial são papiliformes com tamanho reduzido em relação àquelas da face adaxial. Internamente à epiderme da face adaxial, ocorrem três a quatros camadas de parênquima paliçádico, seguido de parênquima esponjoso com grandes espaços intercelulares (Fig. 47). Em todo o parênquima clorofiliano são visíveis idioblastos contendo compostos fenólicos. Os feixes vasculares que ocorrem no limbo são colaterais. Geralmente, ocorre uma calota de fibras esclerenquimáticas em cada pólo dos feixes de menor porte e uma bainha contínua nos feixes de maior calibre (Fig. 43-47). Também nos feixes vasculares são observados compostos fenólicos nas células do floema e/ou do xilema, inclusive nas fibras. (Fig. 47).

O bordo foliar apresenta, transversalmente, uma dilatação, decorrente da presença da nervura marginal, seguida de uma projeção terminal afilada (Fig. 43, 45). A epiderme, recoberta por espessa cutícula, é constituída de células papiliformes de diversos tamanhos. Compostos fenólicos podem ser visualizados em algumas células epidérmicas. Internamente à epiderme (Fig. 45), na extremidade do bordo, ocorre colênquima seguido internamente por parênquima esponjoso, onde ocorrem idioblastos fenólicos. O feixe vascular do bordo é envolvido por uma bainha esclerenquimática, onde é possível notar compostos fenólicos em várias células. No tecido floemático do feixe vascular, são comuns idioblastos com compostos fenólicos, drusas e monocristais.

A epiderme que recobre a nervura central (Fig. 48) apresenta cutícula espessa em ambas as faces da folha. Internamente à epiderme, ocorre uma camada de colênquima com vários estratos celulares (Fig. 48), sendo mais espessa na face abaxial apresentando idioblastos com compostos fenólicos, drusas e monocristais. Uma calota de fibras envolve o floema e outra calota menor ocorre na face adaxial do feixe vascular (Fig. 46). Esse tem formato de ferradura e é colateral, com floema voltado para a face abaxial. Ambos, floema e xilema possuem fibras e idioblastos fenólicos (Fig. 48).

\section{Discussão}

As folhas do gênero Bauhinia são caracterizadas por uma nervação particular, onde as nervuras primárias partem da base da lâmina, próximo à inserção do pecíolo, sendo consideradas palmatinérveas por Vaz \& Tozzi (2003), embora outros autores acreditem que cada espécie possui um padrão de venação particular (Seetharam \& Kotresha 1998). Além disso, as espécies do gênero possuem dois pulvinos característicos, um proximal, na junção do pecíolo com o caule e outro distal, na junção do pecíolo com o limbo, além de uma articulação, denominada de almofada motora (Vaz \& Tozzi 2003), a qual está inserida na base da lâmina foliar e unida ao pulvino distal.

As folhas desse gênero podem ser simples (ou unifolioladas), bilobadas (ou com forma de borboleta) ou bifolioladas (Cusset 1966). Vaz \& Tozzi (2003) distinguem as folhas de Bauhinia de outros gêneros bifoliolados - como Hymeneae e Peltogyne - pela ausência de peciólulos perfeitamente individualizados em Bauhinia.

A interpretação da morfologia foliar do gênero é bastante dificultada, especialmente em relação ao padrão de venação foliar, já que o caminho evolutivo em Bauhinia é controverso. Não há concordância entre os autores, denominados "separatistas" e "fusionistas" (Pijl apud Vaz \& Tozzi 2003). Os "separatistas" consideram que as folhas bifolioladas são derivadas de outras bilobadas que separaram completamente seus lobos, e as folhas bilobadas, por sua vez, são derivadas de folhas simples que sofreram uma inibição apical, conforme cita Cusset (1966). No entanto, para os "fusionistas" o caminho é inverso, sendo consideradas como mais primitivas as folhas compostas bifolioladas, as quais originam as folhas bilobadas e essas, as folhas simples. Essa teoria leva em conta também a posição da família Leguminosae em relação à ordem Fabales, onde uma das principais características que a distingue das demais famílias é a ocorrência de folhas compostas com pulvinos bem evidentes (Judd et al. 1999).

Nesse trabalho, opta-se por considerar as folhas de Bauhinia como compostas, adotando a teoria fusionista e concordando com Vaz \& Tozzi (2003) que consideram "a folha de Bauhinia como uma forma derivada de folha composta bifoliolada, cujos folíolos apresentam-se fusionados em distintos graus ou, são livres entre si e, cujos peciólulos, foram suprimidos".

Através das observações de B. variegata e B. forficata, realizadas no presente trabalho, atribui-se 

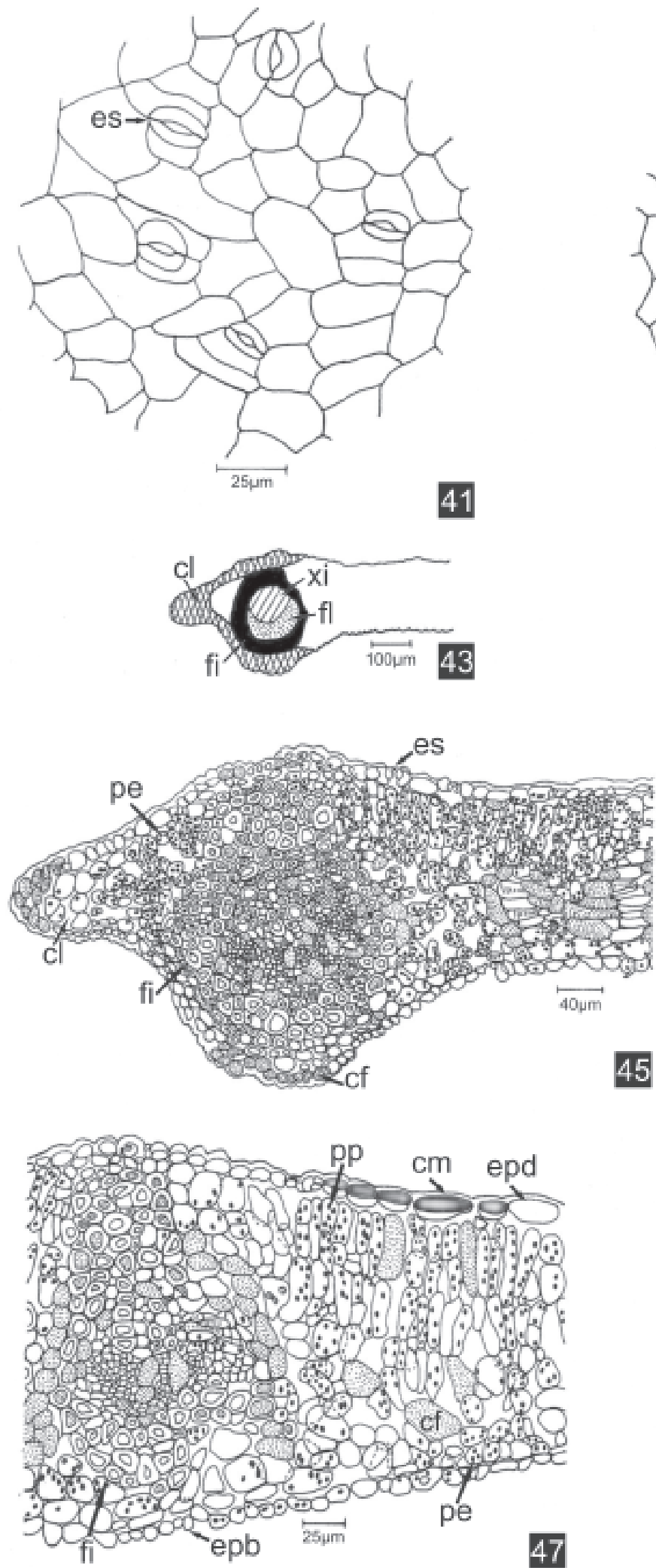
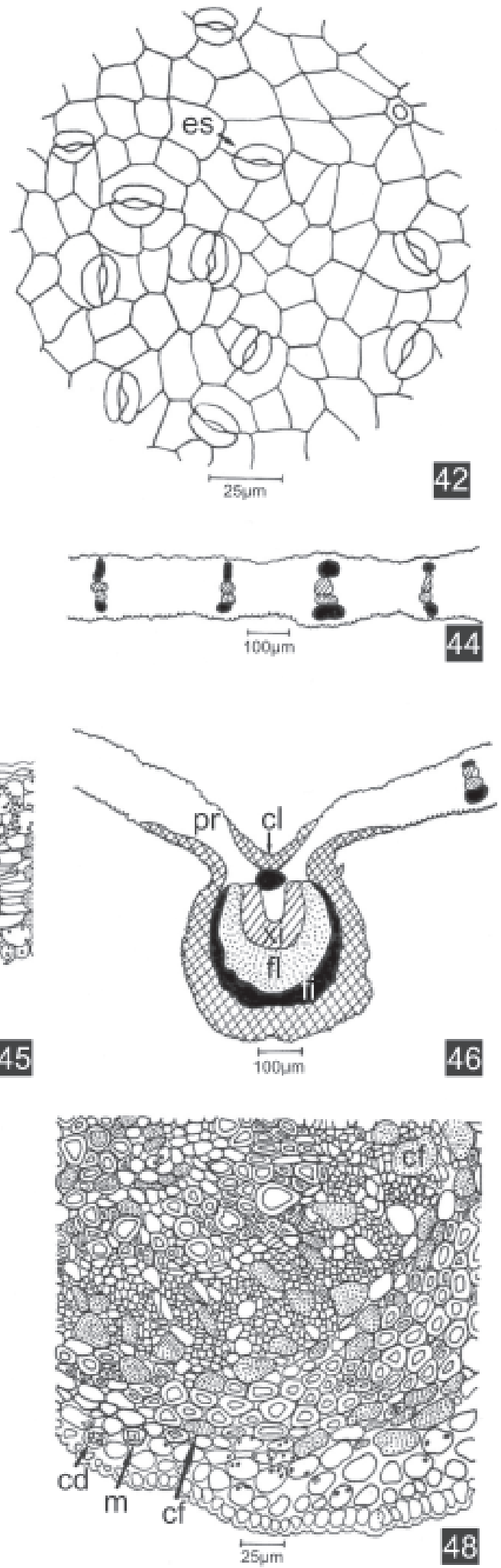

Figuras 41-48. Bauhinia variegata Linn. 41 e 42. Secções paradérmicas. Demais figuras, secções transversais. 41. Epiderme da face adaxial. 42. Epiderme da face abaxial. 43. Diagrama do bordo. 44. Diagrama do limbo, região mediana. 45. Detalhe dos tecidos do bordo. 46. Diagrama da nervura central. 47. Detalhe dos tecidos do limbo, região mediana. 48. Detalhe dos tecidos da nervura central. (cf - compostos fenólicos, cl - colênquima, cm - célula mucilaginosa, epb - epiderme da face abaxial, epd - epiderme da face adaxial, es - estômato, fi - fibras, fl - floema, $\mathrm{m}$ - monocristais, pe - parênquima esponjoso, pp - parênquima paliçádico, xi - xilema). 
208 Lusa \& Bona: Análise morfoanatômica comparativa da folha de Bauhinia forficata Link e B. variegata Linn. ...

o padrão de venação actinódromo (Hickey 1974) para ambas. Esse mesmo padrão foi atribuído para Bauhinia galpinii NE.Br., Bauhinia racemosa Lam., Bauhinia acuminata Linn. e Bauhinia tomentosa Linn., por Seetharam \& Kotresha (1998).

Seetharam \& Kotresha (1998) consideram o padrão de nervação foliar, um importante instrumento para a diferenciação das espécies do gênero e estabelecem três padrões para 12 espécies de Bauhinia. Desta forma, enquadram Bauhinia rufescens Lam., Bauhinia retusa Roxb. e Bauhinia phoenicea Heyne no padrão acródromo; B. galpinii, B. racemosa, B. acuminata e B. tomentosa dentro do padrão actinódromo; e Bauhinia vahlii W. \& A., Bauhinia hookeri F. Muell, Bauhinia malabarica Roxb., Bauhinia purpurea Linn. e $B$. variegata, no padrão campilódromo.

Tratando a folha de Bauhinia como composta, acredita-se que o padrão de venação foliar deva ser atribuído a cada lobo separadamente, como se os folíolos fossem lâminas, conforme a classificação de Hickey (1974). Ainda, de acordo com tal classificação, ambas as espécies aqui analisadas - B. forficata e $B$. variegata - possuem o padrão de nervação actinódromo. Assim, discorda-se de Seetharam \& Kotresha (1998) quanto ao padrão campilódromo descrito para $B$. variegata, já que, este padrão é definido por Hickey (1974), como contendo nervuras primárias ou suas ramificações originando-se num ponto único e formando arcos muito desenvolvidos e recurvados, antes de convergirem ao ápice da folha. Essa organização não é observada nessa espécie. Ainda, Hickey (1974) define arcos recurvados, da seguinte maneira: "arqueando-se basalmente por uma parte de sua trajetória", o que reforça a idéia de que o padrão campilódromo não é adequado para $B$. variegata, já que os arcos são curvados e nunca recurvados.

Em relação à estrutura anatômica do pulvino, Rodrigues \& Machado (2006) afirmam que a presença de ondulações na superfície do pulvino é uma das características que o diferencia do pecíolo e da lâmina foliar e está diretamente relacionada com a maior capacidade de movimentação dessa região foliar. Em $B$. forficata e $B$. variegata essa característica foi observada. Conforme Esau (1977), o maior volume do pulvino é ocupado por células parenquimatosas, sendo que o sistema vascular fica concentrado no centro da estrutura. Esse fato também foi observado nas espécies estudadas.

Bauhinia forficata e B. variegata compartilham algumas características histológicas do córtex no pulvino proximal com nove espécies de Leguminosae (Andira humilis Mart. ex Benth., Bauhinia rufa (Bong.) Steud., Copaifera langsdorffii Desf., Dalbergia miscolobium Benth., Mimosa flexuosa Mart., Mimosa rixosa Mart.,
Stryphnodendron polyphyllum Mart., Zornia diphylla Linn. e Senna rugosa (G. Don) Irwin \& Barneby), descritas por Rodrigues \& Machado (2006). Dentre essas características, destaca-se a ocorrência de um amplo córtex parenquimático, poucas fibras ou ausência delas no floema, a presença de substâncias fenólicas e de cristais na forma de drusas. Segundo os autores, tais características asseguram a flexibilidade do pulvino. Além disso, as células parenquimáticas do córtex externo, denominadas motoras, são consideradas as principais responsáveis pelos movimentos foliares.

De acordo com as observações de Rodrigues \& Machado (2006) e também com aquelas realizadas nesse trabalho, na região cortical externa, as células parenquimáticas são mais volumosas e apresentam núcleos evidentes, forma poliédrica e paredes delgadas sinuosas. A ocorrência dos espaços intercelulares pode facilitar as mudanças na forma e tamanho celular durante a curvatura do pulvino (Fleurat-Lessard \& Millet 1984). A presença de substâncias fenólicas no córtex de B. variegata, assim como citado por Rodrigues \& Machado (2006) para B. rufa, C. langsdorffii, D. miscolobium, M. rixosa e M. flexuosa, parece confirmar a importância dessas substâncias, especialmente os taninos, nos movimentos násticos (Moysset \& Simón 1991).

Observou-se que, no córtex do pulvino de B. forficata, a ocorrência de idioblastos com compostos fenólicos não é freqüente. De acordo com Rodrigues \& Machado (2006), tal característica está relacionada com o movimento do pulvino, pois em $Z$. diphylla, que exibe movimentos heliotrópicos lentos, não foram detectadas substâncias fenólicas nas células motoras. No entanto, somente através de uma observação criteriosa a campo, poder-se-ia inferir sobre a movimentação foliar das espécies analisadas.

Em B. forficata e B. variegata foram observados cristais drusíferos, no parênquima cortical de ambas, apresentando-se em maior número em $B$. variegata. Além disso, no floema de $B$. variegata também foram observados esses cristais. Cristais na forma de drusas também foram registrados em algumas células do córtex externo de $B$. rufa, assim como cristais prismáticos no floema da mesma espécie, e em $S$. rugosa e A. humilis (Rodrigues \& Machado 2006).

Nos pulvinos proximal e distal de B. forficata e B. variegata foi verificada a presença de uma bainha amilífera na região cortical interna, junto às camadas de tecido colenquimatoso, o que também foi descrito por Donato (1995) para B. forficata. Além disso, também foi verificada a presença de grãos de amido na medula parenquimática do pecíolo de ambas as espécies tratadas nesse estudo (sendo a ocorrência de amido, visivelmente 
maior em B. forficata). Tal ocorrência não foi registrada por Donato (1995). O pulvino distal de B. forficata e $B$. variegata apresenta estrutura muito semelhante entre as espécies estudadas. Aspecto similar também foi descrito por Dubey et al. (1990) para B. purpurea e por Vieira (1995) para Bauhinia radiata Vell..

Ainda, tratando da descrição dos pulvinos, Donato (1995) descreve tanto o pulvino proximal, quanto o distal de $B$. forficata, de modo muito semelhante ao realizado nesse trabalho. No entanto, não cita a ocorrência de tecido colenquimatoso circundando o sistema vascular em ambos os pulvinos. Além de nossa constatação, Rezende (1987, apud Vieira 1995) descreveu, para B. forficata e Bauhinia bongardii Steud., um tecido colenquimático envolvendo o sistema vascular nos pulvinos.

Em relação ao pecíolo, tanto $B$. forficata quanto $B$. variegata apresentam duas expansões adaxiais, promovidas por feixes colaterais, e bainha esclerenquimática envolvendo o sistema vascular, o que foi também descrito por Donato (1995) para B. forficata. Expansões adaxiais no pecíolo, também são compartilhadas por B. purpurea (Dubey et al. 1990).

Tanto $B$. forficata quanto $B$. variegata, apresentam uma bainha de fibras envolvendo o sistema vascular no pecíolo. No entanto, a natureza dessas fibras é diferenciada, sendo libriforme em $B$. forficata e gelatinosa em B. variegata. De acordo com Scatena \& Dias (2006), as fibras de natureza gelatinosa são pobres em lignina e possuem grande quantidade de alfa-celulose, que promove a absorção de muita água, podendo intumescer-se ou contrair-se (perda de água). Ainda, segundo esses autores, as fibras gelatinosas são características de tecidos com torção.

Ambas as faces do limbo de $B$. variegata e a face abaxial do limbo de $B$. forficata, assim como os pulvinos e pecíolos de ambas as espécies, são recobertos por dois tipos de tricomas: tectores, de diversos tamanhos (unicelulares e multicelulares unisseriados) e glandulares naviculares (multisseriados), conforme Metcalfe \& Chalk (1965). De acordo com Vaz \& Tozzi (2003), esses tricomas são encontrados na maioria das espécies de Bauhinia sect. Pauletia, à qual pertence B. forficata. Essa descrição também foi realizada por Donato (1995) e por Espíndola Junior (2006) para B. forficata. Segundo Metcalfe \& Chalk (1965) os tricomas glandulares naviculares são comuns em espécies de Bauhinia.

Watson (1942) afirma que o formato das paredes anticlinais, das células epidérmicas, está especialmente relacionado com o ambiente em que as espécies estão inseridas. No presente estudo, tanto $B$. forficata, quanto $B$. variegata apresentaram, em vista frontal, paredes anticlinais levemente curvas. Espíndola Junior (2006) registra para B. forficata células com paredes sinuosas, provavelmente por serem oriundas de um ambiente sombreado. No presente estudo, as folhas de B. forficata foram coletadas em árvores expostas à plena radiação solar, o que justifica as paredes levemente curvas.

Atroch et al. (2001) descrevem aspectos anatômicos de plantas jovens de B. forficata, submetidas a diferentes condições de sombreamento. Observaram que, de modo geral, as folhas de B. forficata apresentam a epiderme da face adaxial com poucos estômatos, que se localizam próximos às nervuras e grande número de estômatos na face abaxial, o que condiz com nossas observações em folhas completamente desenvolvidas.

A respeito dos estômatos, Wilkinson (1979) afirma que os mesmos, associados às células epidérmicas, providenciam características diagnósticas importantes taxonomicamente, tais como: a presença ou ausência na epiderme das faces adaxial ou abaxial e o arranjo das células epidérmicas adjacentes às células-guarda. Constatou-se que ambas as superfícies de $B$. forficata e $B$. variegata possuem estômatos, apesar de serem raros na superfície adaxial de $B$. forficata e restritos às proximidades das nervuras, o que está de acordo com as descrições de Espíndola Junior (2006). Embora esse autor tenha classificado os estômatos de B. forficata, ocorrentes na face abaxial, como sendo do tipo anisocítico, de acordo com a classificação de Wilkinson (1979) verificou-se que os estômatos dessa espécie são do tipo anomocítico, pois as células epidérmicas comuns que circundam as células estomáticas não diferem das demais e se apresentam em número variável.

Bauhinia variegata possui, em ambas as faces e em menor quantidade na superfície adaxial, estômatos do tipo anomocítico, portanto diferente do observado por Kotresha \& Seetharam (1995), que descrevem os padrões dos estômatos para 12 espécies de Bauhinia, entre elas $B$. variegata, com estômatos anisocíticos na face adaxial e tetracíticos, na abaxial.

Segundo Atroch et al. (2001), na epiderme de $B$. forficata há grande número de tricomas cônicos. Porém os autores não citam a presença de tricomas glandulares. Conforme nossas observações, tanto as folhas jovens, quanto as adultas de B. forficata, possuem além de tricomas tectores, tricomas glandulares naviculares.

A epiderme da folha de $B$. forficata e $B$. variegata apresenta cera epicuticular em ambas as faces. Tal característica foi relatada também por Espíndola-Junior (2006) referindo-se a presença de ornamentações nas paredes das células epidérmicas de B. forficata. O mesmo padrão de cera epicuticular foi relatado por Vieira \& Machado (1992) para B. radiata.

Em relação à anatomia das diferentes porções do limbo, as espécies $B$. forficata e $B$. variegata 
demonstraram diferenças marcantes entre si. De modo geral, no bordo, uma expansão lateral na extremidade ocorre em B. variegata, a qual é inexistente em $B$. forficata; e na nervura central, os tecidos ocupam a estrutura de modo bastante diferenciado. Além disso, em $B$. forficata, ocorre somente o parênquima clorofiliano paliçádico, enquanto que em $B$. variegata, o parênquima clorofiliano é representado pelos tipos paliçádico e esponjoso, contendo nessa espécie, inúmeros idioblastos fenólicos.

O bordo da folha de B. forficata é descrito por Donato (1995), como sem curvatura e mais espesso que o restante do limbo, diferindo em parte das observações realizadas nesse trabalho. Esse fato pode ser interpretado, como uma variação relativa ao ambiente em que a espécie encontra-se inserida. Vieira (1995) demonstra justamente essa situação, descrevendo as folhas de $B$. radiata submetidas a três diferentes condições ambientais. O bordo das folhas de sol de B. radiata apresenta curvatura, enquanto que nas folhas de sombra, o bordo apresenta a mesma espessura do mesofilo (sem nenhuma curvatura).

As espécies $B$. forficata e $B$. variegata são diferentes em vários aspectos, como a morfologia das folhas, indumentária, consistência e venação do limbo e quanto à anatomia dos pulvinos, pecíolo e limbo (Tab. 1). As características morfológicas e anatômicas descritas nesse estudo contribuem para a identificação de B. forficata e B. variegata, sendo importantes para a diferenciação das duas espécies, no controle de qualidade de material destinado à pesquisa e a indústria farmacêutica. B. forficata é uma planta de grande interesse pela comunidade farmacêutica, sendo a sua descrição morfoanatômica requisitada pela Farmacopéia Brasileira, pois ambas as espécies aqui descritas são frequientemente misturadas.

Tabela 1. Caracteres morfoanatômicos diferenciais entre as espécies Bauhinia forficata Link e Bauhinia variegata Linn.

\begin{tabular}{lll}
\hline Características distintivas & B. forficata & B. variegata \\
\hline Cor da flor & branca & rosa \\
Aspecto da folha & alongado & alargado \\
Porção do limbo onde os folíolos se unem & mediana & terminal \\
Ápice foliolar & agudo & obtuso \\
Base foliar & levemente cordada & pilosa \\
Superfície adaxial do limbo & glabra & ausente \\
Mucro entre os folíolos & presente & cartácea \\
Consistência da folha & herbácea & curvadas / margens, ápice e base \\
Nervuras secundárias/distribuição & curvadas/uniforme & percurrentes, simples/ramificadas \\
Nervuras terciárias & percurrentes, simples & ortogonais \\
Nervuras qüinqüenarias & dispostas ao acaso & arredondado \\
Formato do pecíolo & elíptico & fibras gelatinosas \\
Constituição da bainha de fibras no pecíolo & fibras libriformes & presente \\
Colênquima nos pulvinos & ausente & arredondado com projeção \\
Forma do bordo do limbo (transversalmente) & arredondado & terminal \\
& & mais conspícuo \\
Colênquima/nervura central & menos conspícuo & ferradura \\
Forma do feixe vascular/nervura central & meia-lua & descontínua \\
Bainha de fibras/nervura central & completa & mais conspícuos/homogênea \\
Idioblastos fenólicos/distribuição & menos conspícuos/epiderme e & mais conspícuos \\
Idioblastos cristalíferos nos pulvinos & parênquima vascular & menos conspícuos \\
\hline
\end{tabular}

\section{Agradecimentos}

À especialista Rose Bortoluzzi, pela identificação das espécies; ao Laboratório de Botânica Estrutural do Departamento de Botânica da UFPR, pela infraestrutura e material de consumo disponibilizados; ao Centro de Microscopia Eletrônica da UFPR pelo uso dos equipamentos e apoio técnico para as análises em MEV.

\section{Referências bibliográficas}

Atroch, E.M.A.C.; Soares, A.M.; Alvarenga, A.A. \& Castro, E.M. 2001. Crescimento, teor de clorofilas, distribuição de biomassa e características anatômicas de plantas jovens de Bauhinia forficata Link submetidas a diferentes condições de sombreamento. Ciências Agrotécnicas 25: 853-862.

Berlyn, G.P. \& Miksche, J.P. 1976. Botanical microtechnique and cytochemistry. Ames, The Iowa State Press.

Cusset, G. 1966. Essai d'une taxonomie foliaire dans la tribu des Bauhinieae. Adansonia 6: 251-280. 
Donato, A.M. 1995. Anatomia foliar e abordagem fitoquímica de Bauihinia forficata Link. (Leguminosae-Caesalpinioideae) Bradea 6: 357-371.

Dubey, R.K.; Sharma, K.C. \& Pillai, A. 1990. Stem-nod-leaf continuum in Bauhinia purpurea Linn.. Botanical Bulletin Academia Sinica 31: 1-6.

Esau, K. 1977. Anatomy of seed plants. $2^{\text {nd }}$ ed. New York, John Wileys and Sons.

Espíndola Junior, A. 2006. Morfolologia e anatomia foliar de duas espécies medicinais (Mikania glomerata Spreng. Asteraceae e Bauhinia forficata Link. - Leguminosae) associadas à erva-mate, sob diferentes condições de luminosidade. Dissertação de Mestrado em Botânica, Setor de Ciências Biológicas, Universidade Federal do Paraná. Disponível em: http://dspace.c3sl.ufpr.br/dspace/bitstream/1884/5761/1/ Disserta\%3F\%3Fo+Ari+Espindola+Junior+Bot\%3Fnica.pdf . (Acessado em: 13/11/2007).

Fleurat-Lessard, P. \& Millet, B. 1984. Ultrastructural features of cortical parenchyma cells (motor cells) instamen of Berberis canadensis Mill. and terciary pulvini of Mimosa pudica L. Journal of Experimental Botany 35: 1332-1341.

Hickey, L.J. 1974. Clasificación de la arquitectura de las hojas de dicotiledoneas. Boletín de la Sociedad Argentina de Botánica 16: 1-26.

Johansen, D.A. 1940. Plant microtechnique. New York, Mc Graw Hill Book.

Judd, W.S.; Campbell, C.S.; Kellog, E.A. \& Stevens, P.F. 1999. Plant Systematics: a phylogenetic approach. Massachusetts, Sinauer Associates.

Kotresha, K. \& Seetharam, Y.N. 1995. Epidermal studies in some species of Bauhinia L. (Caesalpinioideae). Phytomorphology 45: $127-137$.

Kraus, J.E. \& Arduin, M. 1997. Manual básico de métodos em morfologia vegetal. Seropédica, Edur - Editora Universidade Rural.

Lorenzi, H. \& Matos, F.J.A. 2002. Plantas medicinais no Brasil: nativas e exóticas cultivadas. Nova Odessa, Instituto Plantarum.

Menezes, F.S.; Minto, A.B.M; Ruela, H.S.; Kuster, R.M.; Sheridan, H. \& Frankish, N. 2007. Hypoglycemic activity of two Brazilian Bauhinia species: Bauhinia forficata L. and Bauhinia monandra Kurz. Revista Brasileira de Farmacognosia (Brazilian Journal of Pharmacognosy) 17: 8-13.

Metcalfe, C.R. \& Chalk, L. 1965. Anatomy of dicotyledons: leaves, stem and wood in relation to taxonomy with notes on economic uses. v.1. New York, Oxford University Press.

Moysset, L. \& Simón, E. 1991. Secondary pulvinus of Robinia pseudoacacia (Leguminosae): structural and ultrastructural features. American Journal of Botany 78: 1467-1486.

O'Brian, T.P.; Feder, N. \& McCully, M.E. 1965. Polychromatic staining of plant cell walls by toluidine blue O. Protoplasma 59: $368-373$.
Oliveira, C.Z.; Maiorano V.A.; Marcussi, S.D; Sant'Ana, C.D.; Januário, A.H.; Lourenço, M.V.; Sampaio, S.V.; França S.C.; Pereira P.S. \& Soares, A.M. 2005. Anticoagulant and antifibrinogenolytic properties of the aqueous extract from Bauhinia forficata against snake venoms. Journal of Ethnopharmacology 98: 213-216.

Pepato, M.T.; Baviera, A.M.; Vendramini, R.C. \& Brunetti, I.L. 2004. Evaluation of toxicity after one-months treatment with Bauhinia forficata decoction in streptozotocin-induced diabetic rats. BMC Complementary and Alternative Medicine 4: 1-7.

Rajkapoor, B.; Jayakar, B.; Murugesh, N. \& Sakthisekaran, D. 2006. Chemoprevention and cytotoxic effect of Bauhinia variegata against $N$-nitrosodiethylamine induced liver tumors and human cancer cell lines. Journal of Ethnopharmacology 104: 407-409.

Rodrigues, T.M. \& Machado, S.R. 2006. Anatomia comparada do pulvino primário de leguminosas. Revista Brasileira de Botânica 29: 709-720.

Scatena, V.L. \& Dias, E.S. 2006. Parênquima, Colênquima e Esclerênquima in Appezzato-da-Glória, B. \& Carmello-Guerreiro, S.M. Anatomia Vegetal. $2^{\mathrm{a}}$ ed. Viçosa, Editora da Universidade Federal de Viçosa.

Schneider, H. 1977. Indicator hosts for pear decline: symmtomatology, histopathology, and distribution of mycoplasmalike organisms in leaf veins. Phytopathology 67: 592-601.

Seetharam, Y.N. \& Kotresha, K. 1998. Foliar venation of some species of Bauhinia L. and Hardwickia binata Roxb. (Caesalpinioideae). Phytomorphology 48: 51-59.

Silva, K.L. \& Cechinel Filho, V. 2002. Plantas do gênero Bauhinia: composição química e potencial farmacológico. Química Nova 25: $449-454$

Souza, E.; Zanatta L.; Seifriz, I.; Creczynski-Pasa, T.B.; Pizzolatti, M.G.; Szpoganicz, B. \& Silva, F.R.M.B. 2004. Hypoglycemic Effect and Antioxidant Potential of Kaempferol-3,7-O-(r)dirhamnoside from Bauhinia forficata Leaves. Journal Natural Products 67: 829-832.

Vaz, A.M.S.F. \& Tozzi, A.M.G.A. 2005. Sinopse de Bauhinia sect. Pauletia (Cav.) D.C. (Leguminosae: Caesalpinoideae: Cercideae) no Brasil. Revista Brasileira de Botânica 28: 477-491.

Vaz, A.M.S.F. \& Tozzi, A.M.G.A. 2003. Bauhinia ser. Cansenia (Leguminosae: Caesalpinoideae) no Brasil. Rodriguésia 54: 55-143.

Vieira, R.C. 1995. Anatomia da folha de Bauhinia radiata em diferentes ambientes. Arquivos de Biologia e Tecnologia 38: 63-107.

Vieira, R.C. \& Machado, R.D. 1992. Superfície folhar de Bauhinia radiata em dois ambientes. Hoehnea 19: 111-116.

Watson, R.W. 1942. The effect of cuticular hardening on the form of epidermal cells. New Phytology 41: 223-229.

Wilkinson, H.P. 1979. The plant surface in Metcalfe, C.R. \& Chalk, L. Anatomy of dicotyledons. v.1. New York, Oxford University Press. 